\title{
PERBANDINGAN JUMLAH DONASI DARAH SEBELUM DAN SAAT PANDEMI COVID-I 9 DI UTD PMI BANYUMAS TAHUN 2019 DAN 2020
}

\section{Comparison Of Blood Donation Amount Before And During Covid-I 9 Pandemic In Banyumas PMI UTD In 2019 And 2020}

\author{
Ahmad Fauzi ${ }^{\text {I* }}$ \\ Francisca Romana Sri \\ Supadmi ${ }^{2}$ \\ Nurpuji Mumpuni ${ }^{3}$ \\ *IAfiliasi Penulis I, Yogyakarta, \\ DI Yogyakarta, Indonesia \\ ${ }^{2}$ Afiliasi Penulis 2, Yogyakarta, \\ DI Yogyakarta, Indonesia \\ ${ }^{3}$ Afiliasi Penulis 3, Yogyakarta, \\ DI Yogyakarta, Indonesia \\ *email: \\ siskatbd.ayani@gmail.com
}

\section{Kata Kunci:}

Pandemi COVID-19

Donasi darah

Sukarela

Pengganti

\section{Keywords:} COVID-19 pandemic blood donation voluntary substitute

\begin{abstract}
Abstrak
Latar Belakang: Donor darah adalah suatu kegiatan seseorang yang memberikan darahn secara sukarela, kemudia diproses kelayakannya dan ditransfusikan kepada pasien yang membutuhkan. Pendonor darah berasal dari donor darah sukarela atau donor pengganti/keluarga atau dari komunitas tertentu. Pandemi COVID-I 9 adalah penyebaran epidemi coronavirus yang telah menyebar ke berbagai benua dan Negara.

Metode: Penelitian ini merupakan penelitian deskriptif kuantitatif dengan pendekatan waktu yang digunakan adalah retrospektif.

Hasil: Jumlah donasi sebelum pandemi sebanyak 18.661, jumlah donasi saat pandemi sebanyak 22.882 , dan media penyebaran informasi menggunakan aplikasi Whatsapp.

Kesimpulan: Kenaikan jumlah donasi darah selama masa pandemi COVID-19 dan upaya yang dilakukan untuk mempertahankan pendonor agar tetap donor darah di masa pandemi COVID-19.
\end{abstract}

\begin{abstract}
Background: Blood donation is an activity of someone who gives blood voluntarily, then the feasibility is processed and transfused to patients in need. Blood donors come from voluntary blood donors or substitute donors / families or from certain communities. The COVID-19 pandemic is the spread of a coronavirus epidemic that has spread to various continents and countries.

Method: This research is a quantitative descriptive study with a time approach used is retrospective.

Result: The number of donations before the pandemic was 18,661 , the number of donations during the pandemic was 22,882, and media for disseminating information using the Whatsapp application.

Conclusion: The increase in the number of blood donations during the COVID-19 pandemic and the efforts made to keep donors from donating blood during the COVID-I9 pandemic
\end{abstract}

(C) year The Authors. Published by Institute for Research and Community Services Universitas Muhammadiyah Palangkaraya. This is Open Access article under the CC-BY-SA License (http://creativecommons.org/licenses/by-sa/4.0/). DOI: https://doi.org//0.33084/jsm.vxix.xxx.

\section{PENDAHULUAN}

Coronavirus adalah sekumpulan virus yang berasal dari subfamili Orthocoronavirinae atau Coronavirinae yang terdiri atas 4 genus, 23 subgenus dan 38 spesies. Ada 2 jenis penyakit yang disebabkan oleh coronavirus, yaitu Middle East Respiratory Syndrome (MERS) dan Severse Acute Respiratory Syndrome (SARS). Coronavirus Disease 2019 (COVID-19) adalah penyakit corona jenis baru yang belum pernah diidentifikasi sebelumnya. Virus corona adalah jenis virus zoonosis (ditularkan hewan ke manusia). Hewan yang menjadi sumber penularan COVID-19 sampai saat ini belum diketahui. Pandemi coronavirus terjadi di Wuhan, China, pada 31 Desember 2019 yang akhirnya menyebar ke negara lain. Banyak negara terpaksa lockdown demi menurunkan infeksi coronavirus termasuk Indonesia (Isbaniah et al., 2020).

Berdasarkan bukti ilmiah, COVID-19 dapat menular dari manusia ke manusia melalui droplet dan kontak langsung dengan penderita. Untuk meminimalisir 
penyebaran COVID-19 adalah mencuci tangan secara teratur, menghindari kontak dekat dengan siapa pun yang menunjukkan gejala penyakit pernapasan dan menerapkan etika batuk dan bersin yang benar (Isbaniah et al., 2020).

Unit Transfusi Darah Palang Merah Indonesia (UTD PMI) merupakan salah satu unit PMI yang melaksanakan tugas khususnya dalam bidang pelayanan darah. Pelayanan darah yang difasilitasi oleh UTD PMI meliputi pelayanan donor darah, pengolahan komponen darah, dan penyediaan darah. Pelayanan donor darah di UTD PMI mempertimbangkan aspekaspek teknis dengan tujuan untuk memberikan pengalaman donor. Keberhasilan penyelenggaraan upaya kesehatan dapat bekaitan dengan ketenagaan, peralatan, pendonor dan pengolahan guna mengasilkam darah kualitas darah yang aman dan pelayanan yang baik (Suherman, 2017).

Dampak yang dirasakan karena pandemi COVID-19 di bidang kesehatan antara lain terhambat akan layanan penyakit lain, tenaga kesehatan banyak yang gugur dalam bertugas, serta berkurangnya stok darah di bank darah akibat jumlah pendonor yang sangat menurun. Kurangnya stok darah di bank darah menyebabkan penatalaksanaan pasien operasi mengalami penurunan sedangkan permintaan darah pada pasien anemia hemolitik herediter, persalinan dan kanker tetap tinggi (Djuardi, 2020)

Donor darah adalah suatu kegiatan seseorang yang memberikan darahn secara sukarela, kemudia diproses kelayakannya dan ditransfusikan kepada pasien yang membutuhkan. Dalam proses pengambilan darah terdapat banyak tindakan medis seperti penyadapan darah menggunakan jarum sebagai saluran untuk menyalurkan darah dari pembuluh ke kantong darah. Pada proses pengambilan darah, setiap pendonor akan mengalami rasa sakit akibat tusukan jarum dan beberapa reaksi akibat donor darah (Marsya \& Anggraita, 2016)
Pendonor darah berasal dari donor darah sukarela atau donor pengganti/keluarga atau dari komunitas tertentu. World Health Organization (WHO) merekomendasikan donor darah sukarela daripada pengganti. Hasil pemeriksaan donor darah sukarela lebih di utamakan karena untuk keselamatan donor dan keselamatan pasien/penangguhan donor. Penangguhan atau pengecualian permanen dari donor darah karena dicurigai darar pendonor memiliki penyakit infeksi menular lewat transfusi darah, penyakit hematologi, atau kondisi klinis lainnya yang dapat mempengaruhi kualitas darah dan pasien (Roosarjani et al., 2019)

\section{METODOLOGI}

Penelitian ini dilaksanakan di UTD PMI Kab. Banyumas yang dilaksanakan pada bulan Januari - Mei 2021. Desain penelitian ini merupakan penelitian deskriptif kuantitatif dengan pendekatan waktu yang digunakan adalah retrospektif. Penelitian ini menggunakan instrument penelitian berupa lembar laporan tahunan dari seksi Pencari dan Pelestari Donor Darah Sukarela (P2D2S) yang digunakan untuk mengukur gambaran donasi darah.

\section{HASIL DAN PEMBAHASAN}

\section{Jumlah Donasi Donor Darah sebelum Pandemi COVID-19}

Jumlah donor darah sebelum pandemi pada tahun 2019 yaitu pada bulan Maret sampai dengan Desember 2019. Jumlah donasi dibedakan berdasarkan kriteria donasi darah dari pendonor darah sukarela dan pendonor darah pengganti untuk melihat sebaran pendonor, disajikan seperti pada tabel 4.I.

Tabel 4. I Jumlah Donasi Darah Sebelum Pandemi COVID-19 Tahun 2019

\begin{tabular}{|c|c|c|c|}
\hline \multicolumn{4}{|c|}{ Jumlah Donasi Berdasarkan Kriteria } \\
\hline \multirow{3}{*}{ Bulan } & \multicolumn{2}{|c|}{ Pendonor } & Jumlah \\
\hline & Donor Darah & Donor Darah & Total \\
\hline & Sukarela (DDS) & Pengganti (DDP) & \\
\hline
\end{tabular}


Ahmad Fauzi, Francisca Romana Sri Supadmi, Nurpuji Mumpuni. 2021. Comparison Of Blood Donation Amount Before And During Covid19 Pandemic In Banyumas PMI UTD In 2019 And 2020

\begin{tabular}{llll} 
Januari & 1731 & 0 & 1731 \\
Februari & 1340 & 0 & 1340 \\
Maret & 1615 & 0 & 1615 \\
April & 1753 & 5 & 1758 \\
Mei & 1248 & 0 & 1248 \\
Juni & 1748 & 0 & 1748 \\
Juli & 1436 & 0 & 1436 \\
Agustus & 1546 & 0 & 1546 \\
September & 1839 & 5 & 1844 \\
Oktober & 1480 & 0 & 1480 \\
November & 1398 & 2 & 1400 \\
Desember & 1515 & 0 & 1515 \\
\hline \multicolumn{1}{c}{ Jumlah } & 18649 & 12 & 18661 \\
\multicolumn{2}{c}{ Total } & \multicolumn{3}{c}{}
\end{tabular}

Dari tabel 4.I dapat dijelaskan bahwa jumlah donasi darah sukarela (DDS) tertinggi terjadi pada bulan September sebanyak 1839 donasi, jumlah donasi darah pengganti (DDP) tertinggi terjadi pada bulan April sebanyak 5 donasi dan bulan September sebanyak 5 donasi. Dari data tersebut, dapat ditentukan bahwa jumlah total donasi darah sebelum Pandemi COVID-19 tertinggi terjadi pada bulan September sebanyak 1844 donasi.

\section{Jumlah Donasi Darah Pada Saat Pandemi COVID-19}

Jumlah donor darah pada masa Pandemi COVID19 tahun 2020. Jumlah donasi dibedakan berdasarkan kriteria donasi darah dari pendonor darah sukarela dan pendonor darah pengganti, untuk melihat sebaran pendonor, disajikan seperti pada tabel 4.2.

Tabel 4. 2 Jumlah Donasi Darah Saat Pandemi

\begin{tabular}{lccc}
\multicolumn{4}{c}{ COVID-19 Tahun 2020} \\
\cline { 1 - 2 } Bulan & Jumlah Donasi Berdasarkan Kriteria & \\
& \multicolumn{2}{c}{ Pendonor } & Jumlah \\
& Donor Darah & Donor Darah & Total \\
\cline { 2 - 3 } & Sukarela (DDS) & Pengganti (DDP) & \\
\hline Januari & 1535 & 0 & 1535 \\
Februari & 1314 & 0 & 1314 \\
Maret & 1819 & 248 & 2067 \\
April & 1620 & 937 & 2557
\end{tabular}

\begin{tabular}{lccc} 
Mei & 1737 & 0 & 1737 \\
Juni & 2104 & 0 & 2104 \\
Juli & 1724 & 0 & 1724 \\
Agustus & 2161 & 0 & 2161 \\
September & 1856 & 0 & 1856 \\
Oktober & 1830 & 0 & 1830 \\
November & 1805 & 0 & 1805 \\
Desember & 2192 & 0 & 2192 \\
\hline Jumlah Total & 21697 & 1185 & 22882 \\
\hline \multicolumn{4}{c}{ Sumber : Data Sekunder UTD PMI Banyumas Tahun } \\
\multicolumn{4}{c}{ 2020 }
\end{tabular}

Dari tabel 4.2 dapat dijelaskan bahwa bahwa jumlah donasi darah sukarela (DDS) tertinggi terjadi pada bulan Desember sebanyak 2192 donasi, jumlah donasi darah pengganti (DDP) tertinggi terjadi pada bulan April sebanyak 937 donasi.

\section{Persentase Perubahan Jumlah Donasi Darah}

Persentase perubahan jumlah donasi darah pada saat sebelum dan pada saat Pandemi COVID-19 disajikan sepert pada tabel 4.3.

Tabel 4. 3 Persentase Perubahan Jumlah Donasi Darah Berdasarkan Kriteria Pendonor

\begin{tabular}{|c|c|c|c|c|c|c|}
\hline \multirow{2}{*}{ Bulan } & \multicolumn{3}{|c|}{$\begin{array}{c}\text { Jumlah Donasi Darah } \\
\text { Sukarela (DDS) }\end{array}$} & \multicolumn{3}{|c|}{$\begin{array}{l}\text { Jumlah Donasi Darah } \\
\text { Pengganti (DDP) }\end{array}$} \\
\hline & 2019 & 2020 & $\begin{array}{c}\% \\
\text { Perubahan }\end{array}$ & 2019 & 2020 & $\begin{array}{c}\% \\
\text { Perubahan }\end{array}$ \\
\hline Januari & $173 \mid$ & 1535 & $-11,32 \%$ & 0 & 0 & $0,00 \%$ \\
\hline Februari & 1340 & 1314 & $-1,94 \%$ & 0 & 0 & $0,00 \%$ \\
\hline Maret & 1615 & 1819 & $12,63 \%$ & 0 & 248 & $100,00 \%$ \\
\hline April & 1753 & 1620 & $-7,59 \%$ & 5 & 937 & $99,47 \%$ \\
\hline Mei & 1248 & 1737 & $39,18 \%$ & 0 & 0 & $0 \%$ \\
\hline Juni & 1748 & 2104 & $20,37 \%$ & 0 & 0 & $0 \%$ \\
\hline Juli & 1436 & 1724 & $20,06 \%$ & 0 & 0 & $0 \%$ \\
\hline Agustus & 1546 & 2161 & $39,78 \%$ & 0 & 0 & $0 \%$ \\
\hline September & 1839 & 1856 & $0,92 \%$ & 5 & 0 & $-100 \%$ \\
\hline Oktober & 1480 & 1830 & $23,65 \%$ & 0 & 0 & $0 \%$ \\
\hline November & 1398 & 1805 & $29,11 \%$ & 2 & 0 & $-100 \%$ \\
\hline Desember & 1515 & 2192 & $44,69 \%$ & 0 & 0 & $0 \%$ \\
\hline
\end{tabular}

2019 dan 2020 
Berdasarkan tabel 4.3 dapat dijelaskan bahwa data perubahan jumlah donor darah sukarela (DDS) di UTD PMI Banyumas tahun 2019 dan 2020. Persentase perubahan seperti pada tabel dimana penurunan jumlah donasi terjadi pada bulan April sebanyak 7,59\%. Persentase peningkatan terjadi pada bulan Mei sebanyak $39,18 \%$, bulan Juni sebanyak $20,37 \%$, bulan Juli sebanyak 20,06\%, bulan Agustus sebanyak 39,78\%, bulan September sebanyak 0,92\%, bulan Oktober sebanyak 23,65\%, bulan November sebanyak 29,II\%, dan bulan Desember sebanyak 44,79\%.

Persentase perubahan jumlah donor darah pengganti (DDP) seperti pada tabel dimana penurunan jumlah donasi terjadi pada bulan September sebanyak 100\% dan bulan November sebanyak 100\%. Persentase peningkatan terjadi pada bulan Maret sebanyak 248 (99,47\%).

Pada penelitian ini, penulis juga mengumpulkan data jumlah donasi darah berdasarkan lokasi pengambilan, yaitu di dalam gedung (DG) dan mobile unit (MU). Data jumlah donasi berdasarkan lokasi pengambilan sebelum dan pada saat pandemi seperti pada tabel 4.4.

Tabel 4. 4 Jumlah Donasi Darah Berdasarkan Lokasi

\begin{tabular}{|c|c|c|c|c|c|c|}
\hline \multicolumn{7}{|c|}{ Pengambilan Darah } \\
\hline \multirow{2}{*}{ Bulan } & \multicolumn{3}{|c|}{$\begin{array}{l}\text { Pengambilan Darah di } \\
\text { Dalam Gedung (DG) }\end{array}$} & \multicolumn{3}{|c|}{$\begin{array}{c}\text { Pengambilan Darah di Mobile } \\
\text { Unit (MU) }\end{array}$} \\
\hline & 2019 & 2020 & $\begin{array}{c}\% \\
\text { Perubahan }\end{array}$ & $\begin{array}{c}201 \\
9\end{array}$ & 2020 & $\begin{array}{c}\% \\
\text { Perubahan }\end{array}$ \\
\hline Januari & $|73|$ & 1535 & $-11,32 \%$ & $\begin{array}{c}347 \\
3\end{array}$ & 3763 & $8,35 \%$ \\
\hline Februari & 1340 & 1314 & $-1,94 \%$ & $\begin{array}{c}356 \\
4\end{array}$ & 3642 & $2,19 \%$ \\
\hline Maret & 1615 & 2067 & $27,99 \%$ & $\begin{array}{c}351 \\
3\end{array}$ & 2449 & $-30,29 \%$ \\
\hline April & 1758 & 2557 & $45,45 \%$ & $\begin{array}{c}334 \\
5\end{array}$ & 2573 & $-23,08 \%$ \\
\hline Mei & 1248 & 1737 & $39,18 \%$ & $\begin{array}{c}450 \\
5\end{array}$ & 2783 & $-38,22 \%$ \\
\hline Juni & 1748 & 2104 & $20,37 \%$ & $\begin{array}{c}337 \\
1\end{array}$ & 2624 & $-22,16 \%$ \\
\hline Juli & 1436 & 1724 & $20,06 \%$ & $\begin{array}{c}364 \\
0\end{array}$ & 2781 & $-23,60 \%$ \\
\hline Agustus & 1546 & 2161 & $39,78 \%$ & $\begin{array}{c}309 \\
6\end{array}$ & 3197 & $3,26 \%$ \\
\hline $\begin{array}{l}\text { Septembe } \\
r\end{array}$ & 1844 & 1856 & $0,65 \%$ & $\begin{array}{c}312 \\
2\end{array}$ & 3148 & $0,83 \%$ \\
\hline Oktober & 1480 & 1830 & $23,65 \%$ & $\begin{array}{c}393 \\
5\end{array}$ & 2738 & $-30,42 \%$ \\
\hline $\begin{array}{l}\text { Novembe } \\
r\end{array}$ & 1400 & 1805 & $28,93 \%$ & $\begin{array}{c}357 \\
4\end{array}$ & 2808 & $-21,43 \%$ \\
\hline Desember & 1515 & 2192 & $44,69 \%$ & $\begin{array}{c}367 \\
4\end{array}$ & 2416 & $-34,24 \%$ \\
\hline
\end{tabular}

Sumber : Data Sekunder UTD PMI Banyumas Tahun 2019 dan 2020
Berdasarkan tabel 4.4 didapatkan data donasi darah di dalam gedung di UTD PMI Banyumas tahun 2019 dan 2020. Persentase penurunan donasi darah di dalam gedung terjadi pada bulan Januari sebanyak II,32\% dan bulan Februari sebanyak 1,94\%, persentase peningkatan tertinggi terjadi pada bulan Desember sebanyak $44,69 \%$.

Data donasi darah melalui mobil unit di UTD PMI Banyumas tahun 2019 dan 2020. Persentase penurunan donasi darah mobile unit tertinggi terjadi pada bulan Mei sebanyak $-38,2 \%$, persentase peningkatan tertinggi terjadi pada bulan Januari sebanyak 8,35\%.

\section{Upaya UTD PMI Banyumas dalam Mempertahankan Pendonor di Masa Pandemi COVID-I 9}

Berdasarkan hasil wawancara dengan petugas UTD PMI Banyumas, upaya yang dilakukan guna mempertahan donor lestari agar tetap mendonorkan darahnya di masa Pandemi COVID-19 yang dilakukan melalui berbagai cara baik sosialisasi ataupun ajakan untuk melakukan donasi dengan menggunakan berbagai media diantaranya adalah melalui SMS gateway dan aplikasi Whatsapp, seperti pada tabel 4.5.

Tabel 4. 5 Media Penyebaran Informasi Donor Darah Tahun 2019 dan 2020

\begin{tabular}{cclrl}
\hline \multirow{2}{*}{ Tahun } & \multirow{3}{c}{ Media } & \\
& SMS & Persentase & Whatsapp & Persentase \\
\hline 2019 & 465039 & $76,8 \%$ & 0 & $0 \%$ \\
2020 & 140475 & $23,2 \%$ & 246987 & $100 \%$ \\
Total & 605514 & $100 \%$ & 246987 & $100 \%$
\end{tabular}

Sumber : Data Sekunder UTD PMI Banyumas Tahun 2019 dan 2020

Berdasarkan tabel 4.5, media penyebaran informasi donor darah melalui SMS massal tahun 2019 didapatkan persentase $76,8 \%$ dan tahun 2020 didapatkan persentase $23,2 \%$. Media penyebaran informasi menggunakan aplikasi Whatsapp pada tahun 2019 sebesar $0 \%$ dan pada tahun 2020 sebesar 100\%. 
Ahmad Fauzi, Francisca Romana Sri Supadmi, Nurpuji Mumpuni. 2021. Comparison Of Blood Donation Amount Before And During Covid19 Pandemic In Banyumas PMI UTD In 2019 And 2020

Berdasarkan data yang diperoleh dari Unit Transfusi Darah Palang Merah Indonesia Banyumas tercatat jumlah donasi darah berdasarkan kriteria pendonor, yaitu donor darah sukarela (DDS) dan donor darah pengganti (DDP) sebelum dan saat terjadi pandemi COVID-19. Berdasarkan data yang diperoleh, jumlah donasi darah berdasarkan kriteria pedonor sebelum terjadi pandemi COVID-19 tahun 2019 dengan jumlah total I8.66I donasi (tabel 4.I), sedangkan saat terjadi pandemi COVID-19 tahun 2020 dengan jumlah total 22.882 (tabel 4.2). Terjadi kenaikan jumlah donasi darah. Pada tabel 4.3 dapat dilihat terjadi kenaikan drastis pendonor darah pengganti pada bulan Maret (248 donasi) dan April (937 donasi) tahun 2020. Hal ini disebabkan oleh banyaknya pasien yang membutuhkan transfusi darah karena stok darah sudah mulai menipis. Sehingga pada bulan tersebut banyak pendonor pengganti yang mendonorkan darahnya.

Kenaikan jumlah donasi darah ini terjadi karena tingkat kesadaran masyarakat Kab. Banyumas akan pentingmya donor darah sangat tinggi. Jumlah kenaikan donasi darah dapat dilihat pada gambar 4.I.

Gambar 4. I Jumlah Donasi Darah Sebelum dan Saat Pandemi COVID-19

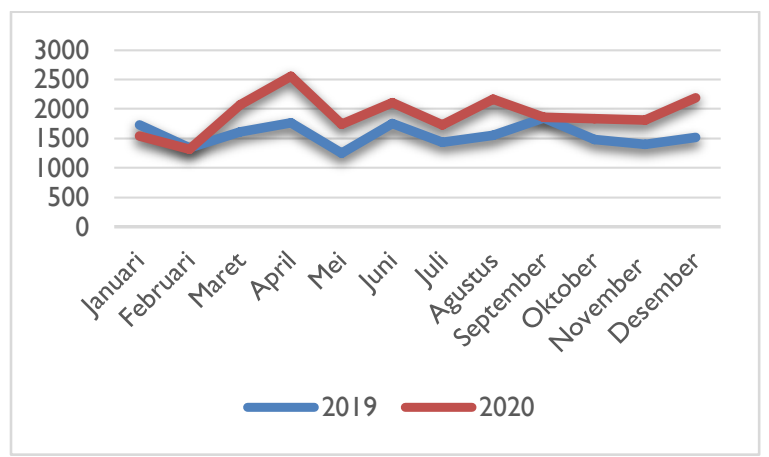

Jika dilihat dari lokasi pengambilan darah (tabel 4.4) peneltian menunjukkan bahwa perbandingan pengambilan darah didalam gedung (DG) terjadi peningkatan donasi darah sedangkan pengambilan darah di mobile unit (MU) terjadi penurunan donasi darah yang dilakukan sebelum terjadi pandemi COVID19 tahun 2019 dan saat terjadi pandemi COVID-19 tahun 2020. Hal ini karena masyarakat lebih nyaman mendonorkan darah mereka langsung ke gedung UTD PMI dari pada MU. Ditambah lagi dengan Unit Transfusi Darah Palang Merah Indonesia Banyumas telah menerapkan protokol kesehatan pencegahan COVID-19 yang sesuai standar WHO, seperti mewajibkan pendonor dan petugas untuk selalu melakukan pengecekan suhu tubuh dan mencuci tangan sebelum memasuki UTD, melakukan pemeriksaan kesehatan, pemeriksaan hemoglobin $(\mathrm{Hb})$ dan tekanan darah dan ruangan pengambilan darah yang telah disterilisasi. Petugas memakai alat pelindung diri yang sesuai, selalu menjaga jarak, serta menerapkan prinsip keselamatan kerja laboratorium yang sesuai standar sebagai tindak pencegahan.

Pengambilan darah melalui mobil unit (MU) terjadi penurunan donasi karena harus mengikuti peraturan protokol kesehatan yang di terapkan pemerintah untuk mengurangi kerumunan. Hal ini disebabkan karena mobil unit dilakukan di tempat terbukan seperti acara adat, acara nasional, sekolah-sekolah, dan perkantoran. Banyak masyrakat takut untuk donor darah melalui mobil unit karena stigma akan penyebaran COVID-I9. Serta sulitnya mengontrol masyarakat ketika mobil unit yang mengakibatkan penerapan protokol kesehatan tidak berjalan sesuai dengan semestinya. $\mathrm{Hal}$ ini sejalan dengan penelitian Djuardi, (2020), bahwa masyarakat tidak perlu khawatir untuk donor darah namun tetap mempraktikkan aspek kewaspadaan dan pencegahan terhadap penyebaran COVID-19.

Berdasarkan penelitian media penyebaran informasi upaya UTD PMI Kab. Banyumas dalam mempertahankan pendonor di masa pandemi COVID19 adalah menggunakan SMS gateway dan aplikasi Whatsapp. Dari data, sebelum terjadi pandemi COVID-19 tahun 2019, media penyebaran informasi yang dilakukan PMI Kab. Banyumas menggunakan SMS gateway (76,8\%). Saat terjadi pandemi COVID-19 tahun 2020, media penyebaran informasi yang dilakukan PMI Kab. Banyumas menggunaka SMS 
gateway $(23,2 \%)$ dan pesan siaran melalui aplikasi Whatsapp (100\%).

Dari hasil wawancara peneliti dengan petugas UTD PMI Kab. Banyumas, perubahan media penyebaran informasi ini dikarenakan pola kehidupan masyarakat lebih banyak menggunakan aplikasi Whatsapp dibandingkan SMS gateway. Oleh karena itu, UTD PMI Kab. Banyumas sejak bulan September tahun 2020 menghentikan penyebaran informasi melalui SMS gateway dan memutuskan menggunakan aplikasi Whatsapp. Namun, pada tahun 202I, UTD PMI Kab. Banyumas mulai aktif menggunakan aplikasi Instagram yang awal diawali dengan seorang public figure untuk mendemonstrasikan donor darah di masa pandemic COVID-19.

UTD PMI Banyumas juga melakukan sosialisasi menggunakan media elektronik untuk mengedukasi pendonor tentang pentingnya penundaan donor darah jika merasa kurang sehat atau sedang menunjukkan gejala COVID-19. Penundaan pendonor darah yang berisiko seperti, orang yang baru sembuh dari COVID19, orang dalam pengawasan (ODP), pasien dalam pengawasan (PDP), orang yang keluar dari zona merah COVID-19. Orang-orang tersebut tidak diizinkan donor darah minimal sampai 28 hari. Dengan demikian masyarakat sehat dapat mendonorkan darahnya secara aman walaupun saat pandemi COVID-19 (Djuardi, 2020).

\section{KESIMPULAN}

Berdasarkan hasil pengolahan data, Jumlah donasi darah sebelum terjadi pandemi COVID-19 tahun 2019 berdasarkan kriteria pendonor darah sukarena dan pendonor darah pengganti sebanyak 18.661 , terjadi kenaikan jumlah donasi darah saat terjadi pandemi COVID-19 tahun 2020 berdasarkan kriteria pendonor darah sukarena dan pendonor darah pengganti sebanyak 22.882. Masyarakat lebih banyak mendonorkan darahnya langsung ke markas UTD PMI Banyumas daripada donor darah di Mobil Unit. Upaya yang dilakukan UTD PMI Kab. Banyumas untuk mempertahankan pendonor agar tetap donor darah di masa pandemi COVID-19, seperti menerapkan protokol kesehatan pencegahan COVID-19 yang sesuai standar WHO, menggunakan berbagai media untuk penyebaran informasi donor darah serta sosialisasi kepada masyarakat.

\section{REFERENSI}

I. Isbaniah, F., Sitompul, P. A., Kusumowardhani, D., Susilo, A., Wihastuti, R., Indawati, W., Saputro, D. D., Setyawaty, V., Kandun, I. N., Wibisono, H., Imari, S., Costy, K, N. W., II, R. K., Bura, V. K., Wulandari, E. W., Sugiarto, A., Dewi, F., Riyadi, S., ... Setyawati, N. (2020). PEDOMAN KESIAPSIAGAAN MENGHADAPI CORONAVIRUS DISESASE (COVID-19) (L. Aziza, A. Aqmarina, \& M. Ihsan (eds.); 3rd ed.). Kementerian Kesehatan RI Direktorat Jenderal Pencegahan dan Pengendalian Penyakit (P2P).

2. Suherman, Y. (20I7). Sistem Aplikasi Bank Darah Pada Palang Merah Indonesia Payakumbuh. Jurnal Sains Dan Informatika, 3(I), 22. https://doi.org//0.22216/jsi.v3il.2329

3. Djuardi, A. M. P. (2020). Donor Darah Saat Pandemi COVID-19. Jurnal Medika Hutama, 02(0I), 298-303. http://jurnalmedikahutama.com

4. Marsya, I. H., \& Anggraita, A. W. (2016). Studi Pengaruh Warna pada Interior Terhadap Psikologis Penggunanya, Studi Kasus pada Unit Transfusi Darah Kota X. Jurnal Desain Interior, I(I),

41. https://doi.org//0.12962/j12345678.vlil.|46I

5. Roosarjani, C., Mayasari, D., Wahyuono, T., Studi, P., Teknologi, D., Darah, B., \& Teknologi, A. (2019). Defferal pada donor darah l,2,3. 9(2), 6366. 